\title{
TANGGAPAN PESERTA DIDIK TERHADAP PEMBELAJARAN PENDIDIKAN AGAMA DI SEKOLAH LANJUTAN TINGKAT ATAS
}

\author{
Qowaid \\ Peneliti Puslitbang Pendidikan Agama dan Keagamaan \\ Badan Litbang dan Diklat Kementerian Agama Republik Indonesia \\ Jl. MH Thamrin No. 06 Jakarta Pusat \\ qowaidbmasyhuri@gmail.com,
}

\begin{abstract}
Religious education in school holds a great deal of importance, as seen by its basis in judgments and its important role in society. Yet critics of religious education implementation and practices still appear in society. Therefore, efforts in searching for weaknesses in religious education in schools are needed, including gathering information on advantages and disadvantages. The Center of Religious Education Research and Development and Religious Life has executed a research survey of the variety of senior high school participants' behavior in the year 2011. The results of the research indicate that, in general, the participants endorse the religious education major. Based on the data, the Indonesian language major was the favorite, while the religious education major was $15^{\text {th }}$ out of 22 major studies. Most of the participants who chose religious education as their favorite cited the importance of religion in real life and the importance of gaining knowledge of one's own religion. Religious education is not among the favorites of participants because of difficulties in the material, the inconvenient way of in which teachers convey the material, and the lessons which require an abundance of memorization, making religious education outside school more interesting to study. Outside of school, religious teachers are considered more convenient, fun, and attractive when conveying knowledge. Religious education, of course, gives positive effects by building character and encouraging good behavior among the participants. Most of the participants agree that religious education should become one of the tests in the national final examinations.
\end{abstract}

Keyword: Participants, Religious Education, Learning.

\section{Abstrak}

Pendidikan Agama di sekolah memiliki posisi yang penting, baik dilihat dari landasan yuridis maupun dari peran strategisnya di masyarakat. Namun demikian, sampai saat ini, masih terdapat sejumlah kritik terhadap implementasi pendidikan agama di sekolah dan implikasinya bagi kehidupan sosial di sekitarnya. Oleh karena itu diperlukan upaya terus menerus untuk menemukan berbagai kelemahan Pembelajaran Pendidikan Agama di Sekolah antara lain melalui penelitian-penelitian untuk memperoleh informasi kelebihan dan kekurangannya. Puslitbang Pendidikan Agama dan Keagamaan Badan Litbang dan Diklat pada tahun 2011 telah melakukan penelitian survei tentang Perilaku Keberagamaan Peserta Didik Sekolah Lanjutan Tingkat Atas. Penelitian ini menghasilkan kesimpulan bahwa umumnya peserta didik menyukai mata pelajaran pendidikan agama. Berdasarkan urutan mata pelajaran yang disukai ternyata Bahasa Indonesia menjadi mata pelajaran terfavorit yang dipilih oleh peserta didik, sedangkan mata pelajaran Pendidikan Agama berada di urutan pilihan ke 15 dari 22 mata pelajaran. Sebagian besar peserta didik yang menyukai pelajaran agama beralasan agama sangat penting bagi kehidupan dan agama yang dianut wajib hukumnya dipelajari. Alasan tidak suka terhadap pendidikan agama karena pada pelajaran pendidikan agama terdapat materi yang sulit dipahami, disusul oleh

Naskah diterima 15 Januari 2013. Revisi pertama, 21 Februari 2013. Revisi kedua, 7 Maret 2013 dan revisi terahir 02 April 2013. 
faktor cara mengajar guru agama yang tidak menyenangkan, kemudian peserta didik beranggapan bahwa pelajaran agama terlalu banyak hafalan dan pelajaran agama di luar sekolah jauh lebih menarik dibandingkan di sekolah. Materi pelajaran dan metode mengajarnya memadai, menyenangkan, guru agama dianggap cukup menguasai pelajaran. Pendidikan Agama berpengaruh positif bagi pembentukan perilaku dan akhlak yang baik di kalangan peserta didik. Sebagian besar peserta didik setuju jika mata pelajaran Pendidikan Agama diujikan secara nasional.

Kata Kunci: Peserta Didik, Pendidikan Agama, Pembelajaran

\section{PENDAHULUAN}

Pendidikan Agama di sekolah memiliki posisi yang penting, baik dilihat dari landasan yuridis maupun dilihat peran strategisnya di masyarakat. Secara yuridis konstitusional landasan tersebut terdapat pada Undang-Undang Dasar 1945, Undang-Undang No 20 tahun 2003 tentang Sistem Pendidikan Nasional, dan berbagai peraturan lainnya. Pada Undang-Undang Dasar 1945 di antaranya tercantum pada Pasal 31 ayat 3 yang menyebutkan bahwa Pemerintah mengusahakan dan menyelenggarakan satu sistem pendidikan nasional, yang meningkatkan keimanan dan ketakwaan serta akhlak mulia dalam rangka mencerdaskan kehidupan bangsa, yang diatur dengan Undang-Undang. ${ }^{1}$

Selanjutnya dalam Undang-Undang No 20 tahun 2003 tentang Sistem Pendidikan Nasional, antara lain disebutkan pada pasal 12 ayat 1a yang berbunyi bahwa "Peserta didik pada setiap satuan pendidikan berhak mendapatkan pendidikan agama sesuai agama yang dianutnya". Beberapa pasal lainnya juga terdapat pada Undang-undang tersebut. ${ }^{2}$ Empat tahun kemudian terbitlah Peraturan Pemerintah Republik Indonesia Nomor 55 Tahun 2007 tentang Pendidikan Agama dan Keagamaan. Di dalamnya antara lain ditetapkan beberapa prinsip pendidikan agama di sekolah. Pada Pasal 2 ayat (1) disebutkan bahwa Pendidikan agama berfungsi membentuk manusia Indonesia yang beriman dan bertakwa kepada Tuhan Yang Maha Esa serta berakhlak mulia dan mampu

${ }^{1}$ Landasan lainnya juga terdapat pada Pembukaan (Preambul) UUD 1945, Pasal31 ayat 5, Pasal 28E (1), Pasal 28J(2), Pasal 29 ayat (1), (2).

${ }^{2}$ Landasan lainnya adalah Pasal 1 , ayat 1 , dan 2, Pasal 3, Undang-undang tentang Sistem Pendidikan Nasional. menjaga kedamaian dan kerukunan hubungan inter dan antarumat beragama. Selanjutnya disebutkan bahwa (2) Pendidikan agama bertujuan untuk berkembangnya kemampuan peserta didik dalam memahami, menghayati, dan mengamalkan nilai-nilai agama yang menyerasikan penguasaannya dalam ilmu pengetahuan, teknologi dan seni. ${ }^{3}$

Dalam konteks yang lebih luas, maka pendidikan di Indonesia merupakan bagian dari upaya mewujudkan cita-cita bangsa untuk mencerdaskan warga negara, menciptakan kesejahteraan umum, dan melaksanakan ketertiban dunia sebagaimana tertuang dalam Preambul UUD 1945. Ikhtiar untuk mencerdaskan kehidupan bangsa dan menciptakan kesejahteraan umum dapat ditempuh antara lain melalui pendidikan, yang di dalam konstitusi dinyatakan sebagai salah satu bentuk hak asasi manusia yang harus dipenuhi negara.

Namun demikian, sampai saat ini, masih terdapat sejumlah kritik terhadap pembelajaran Pendidikan Agama, termasuk Pendidikan Agama Islam. Berbagai kelompok masyarakat menyoroti atau mengkritik implementasi pendidikan agama di sekolah dan implikasinya pada kehidupan sosial di sekitarnya. Pendidikan agama di sekolah-sekolah masih belum berhasil secara maksimal, kalau tidak dikatakan telah gagal mencapai tujuan pendidikan agama, sebagaimana sajian ringkas berikut ini.

Ketua MUI yang juga Rais Aam Pengurus Besar Nahdlatul Ulama (PBNU), KH. Sahal

${ }^{3}$ Landasan lainnya antara lain yang terdapat pada Pasal-pasal lainnya, antara lain Pasal 4 dan 5.Peraturan Pemerintah Nomor 55 tahun 2007 tentang Pendidikan Agama dan Keagamaan. 
Mahfudz ${ }^{4}$, menilai bahwa pendidikan agama di sekolah selama ini ternyata belum bisa mempengaruhi sistem etika dan moral peserta didik. Kegagalan pendidikan agama di sekolah terjadi karena yang berlaku selama ini bukan pendidikan agama melainkan pengajaran agama. Prinsip pendidikan agama seharusnya merupakan upaya menginternalisasikan nilai agama pada peserta didik sehingga mereka dapat memahami dan menerapkan nilai agama dalam kehidupan sehari-hari.

Haidar Bagir - cendekiawan muslim, pendiri sekolah Lazuardi-menyatakan bahwa pendidikan agama kita telah gagal. Agama diperlakukan sebagai kumpulan simbol-simbol yang harus diajarkan kepada anak didik dan diulang-ulang, tanpa memikirkan korelasi antara simbol-simbol ini dengan kenyataan dan aktivitas kehidupan di sekeliling mereka. Dalam hal pemikiran, para peserta didik kerap dibombardir dengan serangkaian norma legalistik berdasarkan aturan-aturan fikih yang telah kehilangan ruh moralnya. Proses pendidikan yang baik harus menggarap sekaligus ketiga ranah tersebut. Haidar mengemukakan dua aspek yang menjadi sebab utama gagalnya pendidikan agama Indonesia. Pertama, karena pendidikan agama selama ini masih berpusat pada hal-hal yang bersifat simbolik, ritualistik dan legal-formalistik. Kedua, pendidikan agama di Indonesia dinilai gagal karena mengabaikan syarat-syarat dasar pendidikan yang mencakup tiga ranah kognitif, afektif dan psikomotorik.

Puslitbang Pendidikan Agama dan Keagamaan Badan Litbang dan Diklat telah melakukan kajian Peraturan dan Perundangundangan Pendidikan Agama pada Sekolah. Telaah isi terhadap peraturan perundangan menyimpulkan beberapa persoalan antara lain bahwa kurikulum Pendidikan Agama terlalu menitikberatkan pada penguatan domain pengetahuan (kognitif), dan kurang pada ranah sikap (afektif) dan ketrampilan (psikomotor);

${ }^{4}$ Harian Kompas. 2003. "Pendidikan Agama di Sekolah Dinilai Gagal”. 31 Mei 2003.

${ }^{5}$ Haidar Bagir. 2003. "Gagalnya Pendidikan Agama”, Harian Kompas, Jum'at 28 Februari 2003. dan, alokasi jumlah jam peserta didikan pada mata pelajaran pendidikan agama dan akhlak mulia kurang memadai. ${ }^{6}$

Berbagai persoalan seputar pendidikan agama tersebut bukan tidak disadari oleh pemerintah. Di dalam rumusan kebijakan, yang saat itu bernama Direktorat Jenderal Kelembagaan Agama Islam, (sekarang bernama: Direktorat Jenderal Pendidikan Islam) di bidang Pendidikan Agama dan Keagamaan Islam disebutkan bahwa kesenjangan antara kesemarakan kehidupan beragama di satu pihak dan perilaku sosial yang betentangan dengan norma agama di lain pihak, kerapuhan etika dan nilai-nilai agama serta kelemahan sendi-sendi moralitas agama telah sampai pada taraf yang memprihatinkan. Perilaku korupsi, kriminalitas, perjudian, perilaku asusila, peredaran dan pemakaian narkoba dan perilaku permisif yang tidak lagi mengindahkan adab kesopanan merupakan bukti rendahnya kualitas pengetahuan, pemahaman, dan pengamalan ajaran agama oleh masyarakat pemeluknya.

Rendahnya kualitas keberagamaan tersebut berkait erat dengan pendidikan agama di semua jenjang yang dinilai belum optimal bagi pengembangan pribadi, watak, dan akhlak mulia peserta didik. Belum optimalnya pendidikan agama di sekolah tersebut disebabkan antara lain oleh muatan kurikulum yang kurang komprehensif (lebih menitikberatkan pada masalah-masalah keakhiratan), keterbatasan dana, sarana dan prasarana, lemahnya penguasaan materi dan metodologi pengajaran, belum optimalnya kegiatan belajar mengajar, serta belum memadainya jumlah dan mutu tenaga kependidikan.?

Direktorat PAIS sendiri telah menginventarissasi sejumlah kekurangan dan telah, se-

${ }^{6}$ Qowaid bersama Ahmad Habibullah dkk. 2008. Kajian Peraturan Dan Perundang-Undangan Pendidikan Agama Pada Sekolah.Jakarta: PT Pena Citasatria, h. 159.

${ }^{7}$ Direktur Jenderal Kelembagaan Agama Islam. 2002. Buku KebijakanDirektur Jenderal Kelembagaan Agama Islam di Bidang Pendidikan Agama dan Keagamaan Islam. Jakarta:Direktur Jenderal Kelembagaan Agama Islam, h.11. 
dang serta terus melakukan perbaikan, baik pada tataran landasan berupa peraturan maupun lingkup operasionalnya. Di dalam Rencana Strategis Direktorat Pendidikan Agama Islam Pada Sekolah Tahun 2010 - 2014 antara lain dinyatakan bahwa selama ini pendidikan Agama Islam di sekolah masih belum mampu memperlihatkan hasil yang memuaskan dalam pencapaian pelbagai tujuan tersebut baik pada peserta didik yang masih berada pada umur interval proses pembelajaran maupun setelah menjadi alumni dan berkiprah di lapangan kerja komunitasnya. Hal ini dapat diindikasikan dari semakin maraknya konflik antar agama, gejala fundamentalisme dan radikalisme yang kian menguat, disorientasi moral relijius di masyarakat, serta konflik sosial yang melibatkan berbagai elemen agama dalam menyikapi realitas yang ada. ${ }^{8}$

Oleh karena itu, diperlukan upaya terus menerus dan berkelanjutan dalam menemukan berbagai kelemahan Pembelajaran Pendidikan Agama di Sekolah antara lain melalui penelitian untuk memperoleh informasi kelebihan dan kekurangannya. Salah satunya adalah mencari informasi mengenai tanggapan peserta didik terhadap penyelenggaraan Pendidikan Agama di sekolah.

Tulisan atau penelitian ini bertujuan untuk mengetahui tanggapan peserta didik terhadap penyelenggaraan Pendidikan Agama di sekolah. Secara lebih rinci tujuannya adalah untuk mengetahui tanggapan atau pendapat peserta didik tentang tingkat ke-suka-an atau ketertarikan baik terhadap Pendidikan Agama beserta alasannya, pendapat terhadap kemampuan guru dalam memberikan pelajaran dan metodenya, tingkat kepuasan terhadap pengajaran guru agama di sekolah, pengaruh pendidikan agama terhadap pembentukan perilaku (akhlak mulia) peserta didik, dan pendapat peserta didik bila pendidikan agama dijadikan Ujian Nasional.

${ }^{8}$ Imam Tholkhah. 2010. Rencana Strategis Direktorat Pendidikan Agama Islam Pada Sekolah Tahun 2010 - 2014. Jakarta:Direktorat Jenderal Pendidikan Islam Kementerian Agama RI., h. 4-5.

\section{Kerangka Konseptual}

Pendidikan Agama di Sekolah adalah pendidikan yang memberikan pengetahuan dan membentuk sikap, kepribadian dan keterampilan peserta didik dalam mengamalkan ajaran agama, yang dilaksanakan sekurang-kurangnya melalui mata pelajaran pada semua jalur, jenjang, dan jenis pendidikan. Penyebutan pendidikan agama ini dimaksudkan agar agama dapat dibelajarkan secara lebih luas dari sekedar mata pelajaran/kuliah agama. Pendidikan Agama dengan demikian sekurang-kurangnya perlu berbentuk mata pelajaran/mata kuliah Pendidikan Agama untuk menghindari kemungkinan peniadaan pendidikan agama di suatu satuan pendidikan dengan alasantelah dibelajarkan secara terintegrasi. Ketentuan tersebut terutama pada penyelenggaraan pendidikan formal dan pendidikan kesetaraan.

Pendidikan Agama di sekolah merupakan bagian dari proses pembelajkaran. Pembelajaran pada dasarnya adalah proses penambahan informasi dan kemampuan baru yang harus dimiliki peserta didik. Dalam konsep dan proses pembelajaran, paling tidak terdapat strategi, metode, pendekatan, model, teknik, dan taktik. ${ }^{9}$ Strategi adalah perencanaan yang berisi tentang rangkaian kegiatan yang didesain untuk mencapai tujuan pendidikan tertentu. Metode adalah cara yang digunakan untuk merealisasikan strategi yang telah ditetapkan. Adapun pendekatan adalah titik tolak atau sudut pandang terhadap proses pembelajaran yang sifatnya masih umum. Teknik adalah cara yang dilakukan seseorang dalam rangka mengimplementasikan metode, sedangkan taktik adalah gaya seseorang dalam melaksanakan suatu teknik atau metode tertentu yang sifatnya lebih individual. Peserta didik adalah anggota masyarakat yang berusaha mengembangkan potensi diri melalui proses pembelajaran yang tersedia pada jalur, jenjang, dan jenis pendidikan tertentu. ${ }^{10}$

${ }^{9}$ Wina Sanjaya. 2012. Strategi Pembelajaran Berorientasi Standar Proses Pendidikan.Jakarta: Kencana, h. 126 $-129$.

${ }^{10}$ Undang-Undang Republik Indonesia Nomor 20 Tahun 2003 tentang Sistem Pendidikan Nasional, Pasal 1 
Dalam proses pembelajaran, posisi peserta didik sangat penting, di samping posisi dan peranan guru, kurikulum, sarana dan prasarana, serta berbagai aspek pendidikan lainnya. Sentral layanan pendidikan di sekolah ada pada peserta didik. Semua kegiatan yang ada di sekolah, baik yang berkenaan dengan manajemen pengajaran, tenaga kependidikan, sarana dan prasarana, keuangan hubungan sekolah dengan masyarakat maupun layanan kusus pendidikan, diarahkan agar peserta didik mendapatkan pelayanan yang baik.

Oleh karena itu, mengetahui tanggapan peserta didik dalam proses pembelajaran juga penting. Dengan adanya informasi tentang tanggapan peserta didik maka akan lebih jelas kondisi Pendidikan Agama di sekolah. Bila tanggapan peserta didik cenderung negatif maka informasi tersebut dapat dijadikan bahan sebagai upaya perbaikan pembelajaran Pendidikan Agama di sekolah.

Tanggapan adalah mengingat kembali sesuatu yang pernah diamati, merupakan gambaran ingatan dari sesuatu pengamatan. Tanggapan merupakan pengalaman kembali atau pengahajatan kembali bekas-bekas yang diterima dahulu dari pengamatan, yang sekarang digambarkan kembali dalam kesadaran. Jadi tanggapan ialah bekas atau gambaran dari sesuatu pengamatan, yang tinggal dalam diri seseorang sehingga menjadi gambaran ingatan. ${ }^{11}$

Tanggapan peserta didik bisa saja dipengaruhi oleh kondisi internal, juga bisa dipengaruhi oleh faktor eksternal, lingkungannya. Hubungan manusia dengan lingkungan sekitarnya merupakan suatu jalinan transactional interdependency atau terjadi saling ketergantungan satu sama lain. Manusia mempengaruhi lingkungannya, untuk selanjutnya lingkungan akan mempengaruhi manusia, demikian pula terjadi sebaliknya. Menurut John Nimpuno,

ayat 4.

${ }^{11}$ Putra. Kaharuddin Eka, dkk. Definisitanggapan http: //kumpulanmakalahdanartikelpendidikan. blogspot. com/2011/02/tanggapan-menurut-psikologi-umum. html, diakes 26 maret 2013, h. 1. sebagaimana dikutip oleh Djumiko, ${ }^{12}$ lingkungan dapat menjadi stimulus atau rangsangan terhadap proses kejiwaan yang menghasilkan pola perilaku tertentu. Perilaku adalah ungkapan kebutuhan internal di dalam diri manusia yang berada di lingkungan ssosial fisik tertentu yang merupakan unsur internal. Perilaku di balik sikap, tanggapan dan tindakan manusia sangat ditentukan oleh persepsi dan kepribadiannya.

\section{METODE}

Puslitbang Pendidikan Agama dan Keagamaan Badan Litbang dan Diklat pada tahun 2011 telah melakukan survei tentang Perilaku Keberagamaan Peserta didik SLTA (SMA, SMK, MA) di Pulau Jawa dan Sulawesi. ${ }^{13}$ Penelitian ini dilakukan dengan menggunakan pendekatan kuantitatif. Target populasi yang menjadi sasaran penelitian adalah seluruh peserta didik sekolah SLTA (SMA, SMK dan MA) di seluruh propinsi di Pulau Jawa dan Sulawesi.

Pemilihan responden dilakukan secara acak bertingkat (stratified random sampling) dengan sasaran 12 propinsi seluruh pulau Jawa dan Sulawesi, yaitu dengan rincian sejumlah 133 kabupaten/kota terpilih (terdiri dari 103 Kabupaten dan 30 Kota), sejumlah 201 sekolah terpilih (SMA, SMK dan MA), dan terdiri dari sejumlah 804 peserta didik terpilih secara acak proporsional. Besaran toleransi kesalahan margin of error (MoE) sebesar 3,45\% pada tingkat kepercayaan $95 \%$ dengan proporsi gender sebesar 50:50.

Selanjutnya untuk dapat memperoleh data penelitian yang terpercaya, dilakukan pengacakan secara bertingkat dimulai dari tingkat kabupaten/kota, sekolah/madrasah, hingga peserta didik secara proporsional.

${ }^{12}$ Djumiko. "Hubungan Timbal Balik antara Penghuni dengan Lingkungannya”. Jurnal Teknik Sipil Dan Arsitektur, Fakultas Teknik Universitas Pembangunan Surakarta. Vol 8. Desember 2010. (12 A), 3-4.

${ }^{13}$ Tim Peneliti. 2011. Studi Perilaku Keberagamaan Peserta didik SMA, SMK dan Madrasah Aliyah (MA) di Pulau Jawa dan Sulawesi. Jakarta: Puslitbang Pendidikan Agama dan Keagamaan, h. 22. 
Prosedur pengacakan di tingkat kabupaten/ kota upaya menjaga kualitas hasil wawancara sebelumnya. Diharapkan dengan spot check ini tidak terjadi kesalahan berarti, baik dari segi metodologis maupun dari segi substansi data yang diperlukan.

Tabel 1. Akurasi Sampel Terhadap Populasi Berdasar Pemeluk Agama

\begin{tabular}{|c|c|c|c|c|c|}
\hline \multicolumn{2}{|c|}{ BPS 2010-AGAMA } & \multicolumn{2}{|c|}{ SURVEI-AGAMA-2011 } & \multirow{2}{*}{$\begin{array}{l}\text { Selisih } \\
-0,4\end{array}$} & Keterangan \\
\hline Islam & 92,42 & Islam & 92,8 & & \multirow{6}{*}{ Valid } \\
\hline Protestan & 4,7 & Protestan & 5,2 & $-0,5$ & \\
\hline Katholik & 1,46 & Katholik & 1,1 & 0,4 & \\
\hline Hindu & 0,44 & Hindu & 0,6 & $-0,2$ & \\
\hline Buddha & 0,64 & Buddha* & 0 & 0,6 & \\
\hline Lainnya & 0,34 & Konghuchu & 0,2 & 0,1 & \\
\hline
\end{tabular}

*Sekolah bercirikan agama Buddha menolak disurvei.

\section{HASIL DAN PEMBAHASAN}

Responden yang menjadi sumber data dalam penelitian ini adalah peserta didik SLTA seluruh pulau Jawa dan Sulawesi yang tercatat dalam database sekolah di website Dapodik Kemendiknas RI pada bulan Juni 2011 sebagai panduan primary sampling survei. Berikut dijelaskan karakteristik responden berdarkan sosio-demografi yang ada, sekaligus data dimaksud menjadi cerminan populasi peserta didik SLTA secara lebih luas.

Karakteristik pertama, adalah pada usia responden yang berkisar antara 16-17 tahun sebesar $73.7 \%$, selebihnya pada $\geq 18$ tahun sejumlah $19 \%$, dan yang berusia $\leq 15$ tahun sejumlah $7,1 \%$. Sasaran responden survei ini memang ditujukan khusus untuk peserta didik SLTA kelas 11 (dua) dan kelas 12 (tiga). Karenanya terlihat sebagian besar adalah pada usia 16-18 tahun. Tetapi, sehubungan kendala teknis lapangan dan keunikan masing-masing sekolah/ madrasah maka didapatkan beberapa responden yang terpilih dari kelas 10 (satu) sehingga ditemukan dalam hasil kategori usia peserta didik yang berusia 15 tahun atau kurang.

Karakteristik peserta didik SLTA kedua adalah pada aspek kedekatan dengan suku bangsa tertentu di Indonesia. Pengakuan responden survei ini umumnya selain sebagai warga negara Indonesia, adalah juga merasa dekat sebagai suku Jawa dinyatakan oleh sejumlah $44,8 \%$, sebagai suku Sunda 22,7\%, Madura sejumlah $6 \%$, Bugis $5,1 \%$, Betawi $3,4 \%$, Gorontalo $1,2 \%$, Buton sejumlah 1,2\%, Makassar $1,2 \%$, Luwu, $0.9 \%$, Toraja, $0,9 \%$, Tionghoa $0,9 \%$, Melayu 0,9\%, Kaili 0,7\%, Minahasa 0,7\%, serta lainnya 9,4\%. Berdasarkan urutan rangking suku terbanyak hingga terkecil komposisi peserta didik menurut suku-bangsa telah sesuai dengan data BPS (Badan Pusat Statistik).

Artinya komposisi suku etnik antara data dari BPS dan hasil survei ini tidak berbeda, atau masih dalam rentang margin error. Khusus untuk pengakuan etnik Jawa dari kalangan peserta didik tergambar menurun jika dibandingkan dengan data BPS yang ada, yaitu mencapai 50,99\% atau terpaut selisih dengan hasil survei ini sebesar $6,2 \%$. Barangkali penjelasan yang bisa disampaikan adalah karena adanya persilangan atau kawin campur yang dilakukan orang tuanya menyebabkan status anak menjadi merasa bukan bagian dari salah satu suku bangsa tertentu, atau karena terlahir di wilayah tertentu sebagai pendatang yang telah lama membaur sehingga merasa sulit menentukan untuk menjadi suku bangsa yang mana, dan atau alasan lainnya yang belum ditelusuri secara mendalam dalam survei ini.

Karakteristik peserta didik SLTA ketiga adalah berdasarkan agama yang dianut. Survei ini mendapatkan data sejumlah $92,8 \%$ adalah beragama Islam, sejumlah 5,2\% menyatakan beragama Protestan, beragama Katholik 1,1\%, Hindhu 0,6\%, dan Konghucu sebanyak 0,2\%. Keterbatasan survei ini adalah tidak mampu menjaring sebaran peserta didik SLTA yang beragama Buddha sehubungan sekolah terpilih yang kebetulan bercirikan agama Buddha menolak untuk disurvei. Namun demikian karakteristik sampel beradasarkan kategori agama ini telah memiliki akurasi yang tepat sesuai data BPS (Badan Pusat Statistik) sehingga dari segi ketepatan sampel dapat dikatakan telah mencerminkan populasi. 
Dari segi pekerjaan, diperoleh latar belakang orang tua peserta didik umumnya adalah masih dominan bekerja sebagai petani/ peternak/nelayan sejumlah $32 \%$. Selanjutnya bekerja di sektor perdagangan $22,7 \%$, bidang industri $20,7 \%$ dan Jasa sebanyak $17 \%$, serta selebihnya lainnya 7,6\%. Bidang pekerjaan orang tua yang terungkap dalam survei ini secara umum telah memiliki kesesusaian dengan data yang dirilis BPS (Badan Pusat Statistik) untuk pulau Jawa dan Sulawesi.

Latar belakang lainnya yang penting juga untuk diungkap dari responden adalah pendidikan orang tua peserta didik. Pernyataan yang disampaikan kepada responden adalah "apa tingkat pendidikan terakhir orang tua/wali yang membesarkan Anda?" Data yang terungkap dari survei ini menyebutkan bahwasanya orang tua peserta didik yang berpendidikan sekolah dasar (SD)/sederajat sejumlah 33,3\%, berpendidikan SLTA/sederajat sejumlah $28 \%$, bependidikan SLTP/Sederajat sejumlah 15,1\%, bependidikan perguruan tinggi/tamat S1 sejumlah 9,6\%, bahkan ada juga yang tidak sekolah sejumlah 2,4\%. Dari data tersebut menunjukkan bahwa selain atensi orang tua peserta didik SLTA terhadap pendidikan sangat tinggi, barangkali adalah dampak dari program wajar dikdas 9 tahun, yaitu wajib belajar hingga SLTA.

Berdasarkan data di atas terungkap bahwa latar belakang pendidikan orang tua peserta didik sangat beragam dari semua jenis pendidikan, hingga yang belum sekolah/tidak sekolah juga turut serta menyekolahkan anakanaknya hingga ke jenjang pendidikan SLTA . Kondisi ini barangkali mengindikasikan partisipasi warga dalam pendidikan sangat tinggi, selain upaya pemerintah untuk penuntasan wajib belajar juga makin intensif.

Salah satu aspek yang diteliti adalah yang berkaitan dengan berbagai pandangan atau tanggapan peserta didik terhadap Pendidikan Agama di Sekolah, yang antara lain berkaitan dengan atensi berupa tanggapan peserta didik terhadap Pendidikan Agama di sekolah. Dalam hal ini difokuskan pada tingkat keseriusan dan perhatian peserta didik dalam mengikuti dan menyikapi pendidikan agama. Artinya seberapa serius tanggapan peserta didik SLTA terhadap mata pelajaran pendidikan agama, apa tanggapan mereka terhadap para pengajar pendidikan agama, dan pandangan peserta didik terhadap kemungkinan diberlakukannya ujian nasional untuk mata pelajaran pendidikan agama. ${ }^{14}$

Pertama, responden dimintakan pendapat tingkat ke-suka-an atau tingkat ketertarikan mereka terhadap mata pelajaran pendidikan agama. Dari data yang ada terungkap bahwasanya sejumlah 61,9\% menyatakan suka dengan mata pelajaran pendidikan agama, dan sebanyak 30,9\% menyatakan sangat suka dengan mata pelajaran pendidikan agama. Selanjutnya terdapat 5,9\% responden menyatakan kurang suka dengan mata pelajaran pendidikan agama, dan 1,1\% menyatakan tidak suka dengan mata pelajaran pendidikan agama, dan $0,2 \%$ menyatakan tidak jawab. Ini berarti umumnya peserta didik SLTA menyukai mata pelajaran pendidikan agama.

Grafik 1. Seberapa Suka Anda terhadap Mata Pelajaran Pendidikan Agama (PA) di sekolah? (\%)

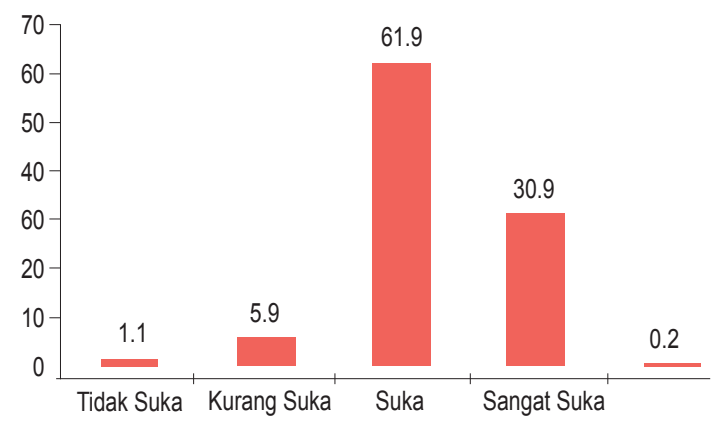

Kedua, pertanyaan berikutnya adalah bagaimana jika mata pelajaran pendidikan agama diperbandingkan dengan mata pelajaran lainnya. Artinya responden ditanya mata pelajaran apa yang paling disukai di sekolah. Jawabnya terungkap bahwasanya sekurangnya terdapat 22 mata pelajaran di sekolah disebut atau dinyatakan oleh responden. Jika diurutkan maka diperoleh data bahwa yang paling disukai adalah mata pelajaran Bahasa Indonesia

\footnotetext{
${ }^{14}$ Ibid., hlm 60 - 71
} 
(14,7\%), kemudian Matematika (11,2\%), Bahasa Inggris (9\%), Penjaskes/Olahraga (6,2\%), Biologi $(4,6 \%)$, Fiqh $(4,5 \%)$, Kimia $(4,1 \%)$, Bahasa Arab (3,9\%), Ekonomi (3,7\%), Geografi (3,6\%), Sejarah (3,5\%), Kesenian (2,9\%), Sosiologi (2,7\%), Fisika (2,7\%), Pendidikan Agama Islam/ PAI (2,5\%), Komputer (2,4\%), Al Qur'an Hadist (1,9\%), Akutansi (1,7\%), Agama (1,6\%).

Berdasarkan urutan di atas, dapat diketahui bahwasanya Bahasa Indonesia menjadi mata pelajaran terfavorit yang dipilih oleh peserta didik SLTA. Diantara sepuluh mata pelajaran yang dipilih paling tervaforit adalah (1). Bahasa Indonesia, (2). Matematika, (3). Bahasa Inggris, (4). Penjaskes/ Olahraga, (5). Biologi, (6). Fiqh, (7). Kimia, (8). Bahasa Arab, (9). Ekonomi, dan (10). Geografi. Sementara untuk mata pelajaran PAI (Pendidikan Agama Islam) terungkap sebagai urutan pilihan ke 15 dari semua jawaban responden yang terjaring.

Perbandingan di atas menunjukkan tingkat keterpilihan mata pelajaran yang paling disukai oleh responden. Ini berarti bahwa semua mata pelajaran di sekolah pada prinsipnya disukai oleh responden, tetapi jika diminta untuk memilih mata pelajaran yang paling disukai akan didapatkan uraian sebagaimana disampaikan di atas.

Memahami pendidikan agama bukan pilihan pertama atau sekurangnya bukan sebagai 5 (lima) pilihan yang pertama barangkali diduga karena mata pelajaran agama tidak diujikan secara nasional dibanding mata pelajaran Bahasa Indonesia, Matematika dan Bahasa Inggris serta Biologi. Atau malah memberikan makna bahwa memang mata pelajaran pendidikan agama adalah mata pelajaran yang sulit dalam pelaksanaannya.

Lepas dari benar atau tidak asumsi di atas, terdapat suatu kondisi di mana peserta didik tidak diberikan kesempatan untuk menolak satu mata pelajaran tertentu yang tidak disukai atau kurang disukai atau yang tidak diinginkannya untuk diikuti. Karena itu dapat dipahami semua pelajaran pasti akan disukai oleh responden.
Grafik 2. jika Anda suka/sangat suka terhadap pelajaran Pendidikan Agama di sekolah, sebutkan alasan paling utama! (\%) N=745

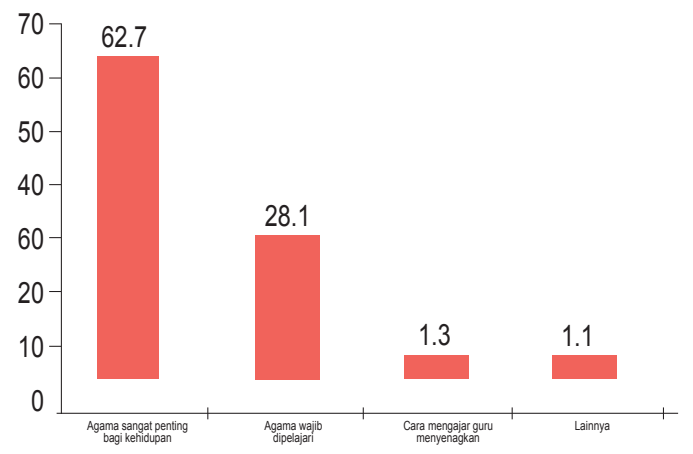

Survei ini selanjutnya menanyakan alasan sukaatau tertarik terhadap mata pelajaran pendidikan agama. Alasan yang diajukan untuk dipilih diantaranya adalah agama sangat penting bagi kehidupan, agama wajib dipelajari, cara mengajar guru yang menyenangkan dan alternatif jawaban lainnya, yaitu diberikan jawaban terbuka/bebas berupa apa saja alasan lain yang diberikan responden.

Terungkap dari data lapangan bahwa sebagian besar peserta didik (62.7\%) yang menyukai pelajaran agama beralasan karena agama sangat penting bagi kehidupan. Sebanyak 28.1\% peserta didik menjelaskan karena agama yang dianut wajib hukumnya diajarkan. Hanya $4.8 \%$ peserta didik yang mengatakan alasan suka karena faktor cara guru mengajar yang dianggapnya menyenangkan. Dan faktor lainnya sejumlah $4,4 \%$.

Data di atas menunjukkan tingginya kesadaran peserta didik akan pentingnya pelajaran agama bagi kehidupan. Kesadaran akan pentingnya pelajaran agama menjadi penting untuk ini sebenarnya adalah modal untuk menjadikan pelajaran agama sebagai sarana dalam membentengi peserta didik dari pengaruh-pengaruh sosial yang negatif.

Alasan dimaksud juga memberikan makna bahwa pelajaran pendidikan agama disukai karena agama bersifat normatif dan sekaligus mendasar, yakni pendidikan agama adalah materi yang harus dipelajarani. Berbeda misalnya dengan mata pelajaran lain yang kemungkinan 
alasannya adalah karena senang berhitung misalnya, bersifat minat dan bakat, atau alasan untuk menguatkan keahlian bidang tertentu yang dipandang sesuai dengan cita-citanya kelak. Pendidikan agama menjadi sesuatu yang tak terpisahkan dalam diri peserta didik, dan karenanya menjadi suka untuk diajarkan.

Data di muka juga menunjukkan bahwa terdapat $5,9 \%$ peserta didik yang menyatakan kurang suka, dan sebanyak 1,1\% menytakan tidak suka terhadap pendidikan agama di sekolah. Ini berarti terdapat $7 \%$ peserta didik yang menyatakan tidak suka dan kurang suka terhadap pendidikan agama di sekolah. Meski prosentasenya hanya 7\% peserta didik SLTA, namun alasan ketidaksukaan dan kekurangsukaan mereka terhadap pelajaran pendidikan agama penting untuk diketahui dan dijelaskan. Kebanyakan peserta didik (32.7\%) menjelaskan bahwa pada pelajaran agama terdapat materi yang sulit dipahami, disusul oleh faktor cara mengajar guru agama yang tidak menyenangkan (21.8\%). Jumlah yang tidak jauh berbeda ada pada alasan peserta didik bahwa pelajaran agama terlalu banyak hafalan (18.2\%) dan alasan bahwa pelajaran agama di luar sekolah jauh lebih menarik dibandingkan di sekolah (16.4\%). Hanya $1.8 \%$ peserta didik yang beralasan bahwa pelajaran agama tidak wajib diajarkan.

Alasan ketidaksukaan peserta didik terhadap pelajaran agama tersebut di atas dapat menjadi bahan evaluasi yang sangat penting bagi para pemangku kepentingan pelajaran pendidikan agama untuk dapat memperbaiki materi dan metode pengajaran pendidikan agama sehingga dapat lebih maksimal lagi penyerapan dan penerimaan pelajaran agama di sekolah.

Dari aspek jumlah materi misalnya, tanggapan peserta didik umumnya sudah menganggap cukup dan memadai, sebagian besar peserta didik menjawab bahwa jumlah materi pelajaran agama di sekolah sudah cukup (77.8\%). Hanya sedikit peserta didik yang menjawab jumlah materi pelajaran agama terlalu banyak (8.3\%) atau terlalu sedikit (13.6\%).
Jadi, menurut peserta didik materi pendidikan agama di sekolah dalam kategori cukup dan memadai sehingga tidak perlu untuk ditambah atau dikurangi lagi.

Sebagai bentuk evaluasi untuk guru mata pelajaran pendidikan agama ditanyakan juga dalam survei ini terkait penilaian peserta didik terhadap kemampuan guru agama dalam menerangkan atau menjelaskan pendidikan agama di sekolahnya. Diungkap oleh responden, bahwasanya sebanyak $65.2 \%$ peserta didik mengatakan bahwa guru agama dipandang sudah cukup jelas dalam menerangkan pelajaran pendidikan agama di sekolahnya. Bahkan, 28.8\% peserta didik mengatakan guru agama mereka sudah sangat jelas dalam mengajar pendidikan agama. Hanya sedikit saja peserta didik yang mengatakan bahwa guru agama mereka tidak atau kurang memiliki kemampuan dalam menerangkan pelajaran agama (6\%). Dengan kata lain, secara umum tidak ada persoalan yang serius terkait persoalan kompetensi guru agama di sekolah.

Hal yang sama disampaikan peserta didik dalam metode guru agama ketika menerangkan pelajaran pendidikan agama. Pengakuan responden menyebutkan ketika ditanya, seberapa menyenangkan cara guru dalam menerangkan pelajaran agama, sebagian besar peserta didik (59.5\%) mengaku cara guru agama mereka cukup menyenangkan dalam menerangkan pelajaran agama. Bahkan, $32.4 \%$ peserta didik mengaku sangat menyenangkan guru mereka dalam menerangkan pelajaran pendidikan agama di sekolahnya. Hanya sedikit peserta didik (8\%) yang mengatakan kurang menyenangkan atau tidak menyenangkan dalam menerangkan pelajaran pendidikan agama di sekolahnya.

Untuk penguasaan mata pelajaran pendidikan agama di sekolah menurut pengakuan peserta didik, sebagian besar guru agama mereka sudah cukup menguasai dan bahkan sangat menguasai dalam mengajar. Sebanyak $53.1 \%$ peserta didik mengatakan guru agama sangat menguasai materi pelajaran pendidikan agama, dan sebanyak $44.1 \%$ yang mengatakan cukup menguasai. Jadi, dalam penilaian peser- 
ta didik, guru sudah cukup menguasai materi pelajaran pendidikan agama. Sebagaimana data-data tentang kompetensi guru sebelumnya bahwa tidak ada persoalan pada kemampuan guru agama mereka dalam hal penguasaan materi pelajaran pendidikan agama. Hanya sedikit peserta didik (2.4\%) yang mengatakan bahwa guru agama mereka kurang menguasai materi pelajaran pendidikan agama.

Hal yang cukup menarik dari penelitian ini terkait dengan gagasan untuk meng-UN kan mata pelajaran Pendidikan Agama (PA) yang sempat menimbulkan kontroversi cukup hangat di kalangan praktisi dan pengamat pendidikan. Survei ini menemukan bahwa dalam perspektif peserta didik SLTA, sebagian besar, yakni 76,3\% ternyata setuju jika mata pelajaran PA diujikan secara nasional. Data ini sekaligus menepis pandangan dari sebagian kalangan yang berkeberatan terhadap peng-UN-an PA dengan alasan peserta didik akan merasa keberatan dan bahkan cenderung menolak.

Grafik 3. Seberapa Setuju Anda dengan Rencana Kebijakan Pemerintah untuk Melaksanakan Ujian Nasional untuk PA? (\%)

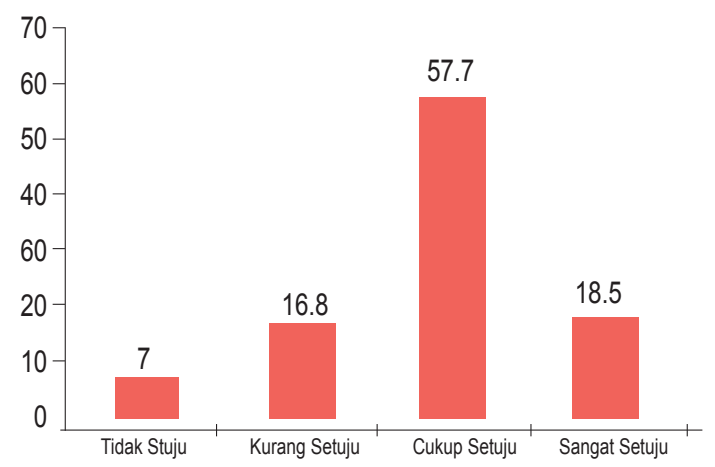

Dari aspek penting-tidaknya pendidikan agama bagi peserta didik SLTA, pengakuan responden terlihat positif. Artinya, secara umum pendidikan agama berpengaruh positif bagi pembentukan perilaku dan akhlak yang baik di kalangan peserta didik SLTA. Pengaruh pelajaran pendidikan agama di sekolah terhadap pembentukan akhlak sosial peserta didik diakui oleh peserta didik sangat besar (58.2\%). Sebagian lainnya berpendapat bahwa pendidikan Agama dirasakan cukup berpengaruh terhadap akhlak/perilaku (35.1\%). Namun, survei ini juga menjaring jawaban dalam kutub ekstrim yang menyatakan bahwa pelajaran agama tidak berpengaruh terhadap pembentukan akhlak sosial peserta didik diungkap oleh sejumlah $2.7 \%$ dan yang berpendapat kurang berpengaruh sebanyak $4 \%$.

Grafik 4. Menurut Anda, seberapa berpengaruh PA di sekolah pada pembentukan akhlak/perilaku Anda dan teman-teman? $(\%)$

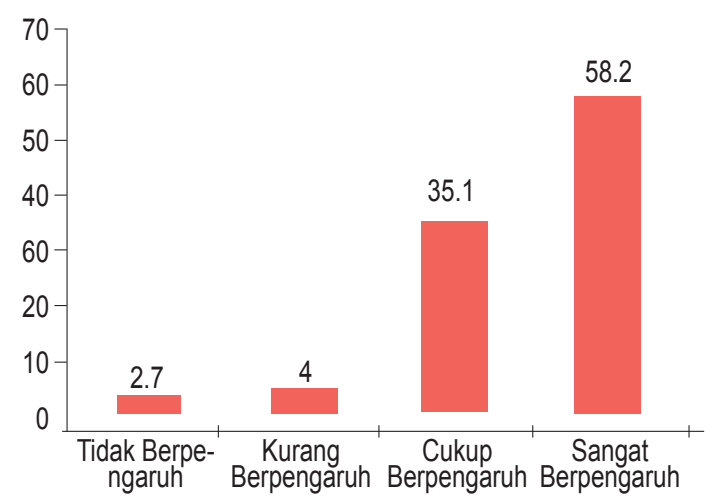

Aspek penting-tidaknya pendidikan juga dapat dilihat dari perbandingan antara kesan pendidikan agama di dalam sekolah dan di luar sekolah. Berdasarkan data yang didapatkan dalam survei ini, umumnya yang mengaku pendidikan agama di sekolah lebih berkesan dibandingkan pendidikan di luar sekolah sebanyak $37.1 \%$. Sebaliknya, $21.2 \%$ peserta didik mengaku pendidikan agama di luar sekolah jauh lebih berkesan dibanding di sekolah. Di sisi lain, terdapat $38.5 \%$ peserta didik yang mengaku sama pengaruhnya pendidikan agama baik di sekolah maupun di luar sekolah.

Membaca hasil data di atas tampaknya perlu hati-hati, meski terlihat secara umum bahwa pendidikan agama di dalam sekolah lebih berkesan dibanding pendidikan agama di luar sekolah. Hal tersebut karena kita tidak bisa memberlakukan data mereka yang menyatakan "pendidikan agama di luar sekolah dan di dalam sekolah sama berkesannya" sebagai bagian dari "pendidikan di dalam sekolah lebih berkesan" atau menjadi bagian dari "pendidikan agama di luar sekolah lebih berkesan". Sebab penyataan "pendidikan agama di dalam sekolah lebih berkesan dibanding di luar sekolah" hanya $37,1 \%$, selebihnya tidak. Ini berarti pendidikan agama luar sekolah masih dipan- 
dang sangat penting. Konsekuensi lainnya adalah bahwa persetujuan responden bahwa pendidikan agama di sekolah dipandang sangat penting ditinjau dari aspek kuantitas masih kurang signfikan.

Oleh karena itu, perlu dilakukan penelusuran terhadap unsur lain dari Pendidikan Agama itu sendiri. Dalam hal ini adalah Guru Pendidikan Agama pada sekolah, khususnya kompetensi guru dan sarana pembelajaran untuk mengetahui kelebihan dan kekurangan yang ada. Puslitbang Penda dan Keagamaan juga telah melakukan penelitian tentang kompetensi Guru Pendidikan Agama Islam pada SMA. Penelitian tentang profil kompetensi guru pendidikan agama Islam pada SMA mengambil sampel GPAI SMAN pada enam kota besar Bandung, DKI Jakarta, Makassar, Medan, Semarang, Surabaya. Hasilnya adalah nilai kompetensi Proses Belajar Mengajar 52,23, kompetensi Pengukuran dan Evaluasi 43,15, kompetensi penguasaan materi 81,21 , dan kompetensi individual dan sosial 83,92. Hal demikian menunjukkan bahwa nilai rata-rata pengetahuan pengelolaan proses belajar mengajar (PBM) dan pengetahuan pengukuran dan evaluasi (PE) dalam kategori kurang. Adapun penguasaan materi peserta didikan PAI, kompetensi individual dan sosial GPAI SMA dalam kategori baik. ${ }^{15}$

Artinya, kelemahan atau kekurangan utama GPAI adalah dalam aspek pengelolaan proses belajar mengajar dan evaluasinya, termasuk di dalam metodenya. Hal demikian tidak jauh berbeda dengan hasil penelitian tentang kompetensi guru pendidikan agama Islam di berbagai daerah yang dilakukan beberapa tahun sebelumnya.

Oleh karena itu diperlukan sejumlah inovasi agar kualitas pembelajaran pendidikan agama semakin meningkat, sebagai bagian dari revitalisasi dan peningkatan kualitas pendidikan agama di sekolah. Diperlukan model, pendekatan, strategi, metode, teknik, dan

${ }^{15}$ Qowaid, dkk. 2003. Profil Guru Pendidikan Agama di Sekolah Umum.Jakarta: Puslitbang Pendidikan Agama dan Keagamaan, h. $81-82$. bahkan taktik yang sesuai dengan kondisi saat ini, agar tercapai tujuan pendidikan agama di sekolah sebagaimana termaktub dalam beberapa landasan yang ada, mulai dari UUD 1945, Undang-undang, Peraturan Pemerintah, dan sejumlah Peraturan lainnya.

Model pembelajaran tersebut mengakomodasi sejumlah permasalahan yang dihadapi Pendidikan Agama Islam di sekolah, antara lain dengan mengintegrasikan berbagai kegiatan seperti kegiatan belajar mengajar (KBM), kegiatan mentoring yang melibatkan secara aktif GPA dan peserta didik sekolah yang bersangkutan, serta kegiatan mandiri, dalam satu sistem penilaian yang komprehensif. Dengan demikian, pembelajaran di kelas, di sekolah, di rumah, dan di masyarakat terpantau secara lebih terukur oleh Guru Pendidkan Agama sesuai dengan tujuan pembelajaran. Strategi pembelajarannya lebih banyak berorientasi pada peserta didik.

Untuk dapat melaksanakannya, diperlukan Guru Pendidkan Agama yang profesional dan memiliki komitmen yang tinggi terhadap tugasnya. Oleh karena itu, peningkatan kompetensi Guru Pendidkan Agama hendaknya selalu terus diupayakan yang dimulai dengan menelusuri aspek yang paling rendah atau kecil tingkat kompetensinya. Dalam hal ini, telah dilakukan beberapa penelitian tentang kompetensi Guru Pendidkan Agama, baik secara khusus maupun bagian dari penelitian yang lebih luas.

Hasil penelitian menunjukkan bahwa kelemahan guru terutama pada aspek metode pembelajaran dan evaluasinya. Hal itu dapat berimplikasi pada kurang maksimalnya pembelajaran. Selanjutnya akan berpengaruh terhadap tingkat keberhasilan Guru Pendidkan Agama dalam membentuk anak didik sesuai prinsip dan tujuan pembelajaran Agama pada sekolah. Bahkan tidak menutup kemungkinan para peserta didik lebih tertarik menerima pendidikan agama di lingkungan sekolah bukan dari GPA mereka, tetapi berasal dari orang lain yang isinya berupa nilai-nilai yang tidak 
sejalan dengan tujuan Pendidikan Agama pada Sekolah.

Selanjutnya diperlukan sejumlah inovasi agar tercapai maksud tersebut. Puslitbang Pendidikan Agama dan Keagamaan telah beberapa kali melaksanakan lomba inovasi pembelajaran Pendidikan Agama Islam di Sekolah. Hasilnya antara lain diperoleh sejumlah metode pembelajaran Pendidikan Agama Islam yang inovatif yang salah satu hasilnya adalah dapat meningkatkan hasil belajar peserta didik. ${ }^{16}$

Salah satu variabel yang banyak berpengaruh terhadap keinovatifan tersebut adalah sikap kemandirian. Hasil penelitian terhadap tenaga fungsional Penyuluh Agama Islam memperlihatkan bahwa kemandirian memiliki pengaruh yang signifikan terhadap inovasi tenaga fungsional Penyuluh Agama Islam. ${ }^{17}$ Temuan tersebut kemungkinan dapat diterapkan untuk meningkatkan kualitas pembelajaran Pendidikan Agama di sekolah.

Disamping meningkatkan kualitas metode pembelajaran juga perlu ditingkatkan kelengkapan sarana prasarana media pembelajaran agar sesuai dengan Standar Nasional Pendidikan (SNP).$^{18}$ Dalam hal ini, pembelajaran berbasis ICT (Information Communication Technology) sangat diperlukan.

Untuk itu, sarana prasarana seperti Laboratorium Pendidikan Agama yang baik perlu dipertimbangkan keberadaanya. Laboratorium merupakan wahana yang dibuat untuk mempermudah menyampaian materi yang terkait

${ }^{16}$ Qowaid dkk. 2007. Inovasi Pembelajaran Pendidikan Agama Islam. Jakarta: Pena Citasatria, h. $8-25$.

${ }^{17}$ Qowaid. 2010. Keinovatifan Dalam Penyuluhan Agama Islam Di Provinsi DKI Jakarta. Dialog, Jurnal Penelitian dan Kajian Keagamaan. Tahun XXXIII No 70. (119-138).

${ }^{18}$ Sesuai Peraturan Pemerintah Nomor 19 Tahun 2005 disebutkan bahwa lingkup Standar Nasional Pendidikan meliputi: standar isi; standar proses; standar kompetensi lulusan; standar pendidik dan tenaga kependidikan; standar sarana dan prasarana; standar pengelolaan; standar pembiayaan;dan standar penilaian pendidikan dengan pembelajaran agama di sebuah ruangan atau tempat tertentu.

Dengan demikian, prinsip pendidikan agama di sekolah yang dilaksanakan secara interaktif, inspiratif, menyenangkan, menantang, mendorong kreativitas dan kemandirian, serta menumbuhkan motivasi untuk sukses hidup semakin terpenuhi. ${ }^{19}$

\section{PENUTUP}

\section{Kesimpulan}

1. Umumnya pelajar SLTA menyukai mata pelajaran pendidikan agama. Namun, mata pelajaran PA (Pendidikan Agama) berada di urutan pilihan ke 15 dari 22 mata pelajaran di SLTA. Sebagian besar peserta didik yang menyukai pelajaran agama beralasan karena agama sangat penting bagi kehidupan. Sebagian lainnya beralasan karena agama yang dianut wajib hukumnya dipelajari. Sebagian peserta didik yang mengatakan alasan suka karena faktor cara guru mengajar yang dianggapnya menyenangkan.

2. Alasan tidak suka terhadap pendidikan agama karena pada pelajaran pendidikan agama terdapat materi yang sulit dipahami, disusul oleh faktor cara mengajar guru agama yang tidak menyenangkan, kemudian peserta didik beranggapan bahwa pelajaran agama terlalu banyak hafalan dan alasan bahwa pelajaran agama di luar sekolah jauh lebih menarik dibandingkan di sekolah, serta sebagian kecil peserta didik beralasan bahwa pelajaran agama tidak wajib dipelajari.

3. Peserta didik umumnya menganggap bahwa materi pelajaran Pendidikan Agama cukup memadai. Sebagian besar peserta didik berpendapat bahwa cara mengajar guru agama dan penggunaan metodenya cukup menyenangkan. Guru dianggap

${ }^{19}$ Peraturan Pemerintah Republik Indonesia Nomor 55 Tahun 2007. Pasal 5 ayat (7). 
cukup menguassai pelajaran Pendidikan Agama.

4. Pelajaran pendidikan agama berpengaruh positif bagi pembentukan perilaku dan akhlak yang baik peserta didik.

5. Sebagian besar peserta didik setuju jika mata pelajaran Pendidikan Agama di sekolah diujikan secara nasional.

\section{Rekomendasi}

1. Dalam hal adanya anggapan bahwa materi Pendidikan Agama di sekolah sulit dipahami oleh peserta didik, maka dari segi materinya disarankan agar ditulisulang dengan bahasa yang sederhana dan mudah dicerna oleh peserta didik. Dalam menyusun, di samping melibatkan penulis yang secara substansi menguasasai materi, juga dilibatkan ahli Bahasa Indonesia yang baik atau penulis yang telah berpengalaman.

2. Dalam hal adanya anggapan peserta didik bahwa faktor cara mengajar guru agama yang tidak menyenangkan, maka disarankan agar kemampuan cara mengajar guru ditingkatkan baik dengan pendidikan dan pelatihan (diklat), pendidikan secara khusus, maupun dengan belajar sambil bekerja (mengajar) dengan bimbingan khusus.

3. Dalam hal ini, disarankan agar sarana pembelajaran yang up to date sangat diperlukan seperti penggunaan dan pemanfaatan teknologi informasi. Guru dilatih agar terampil memanfaatkan sarana tersebut.

4. Karena sebagian besar peserta didik setuju apabila Pendidikan Agama di sekolah di UN kan maka ada baiknya USBN atau ujian sekolah berstandar nasional (belum sampai pada UN) yang saat ini masih dilakukan pada sebagian kecil sekolah dapat diperluas.

5. Terhadap aspek tanggapan peserta didik yang dinilai positif terhadapa berbagai aspek pelaksanaan Pendidikan Agama di sekolah, maka hal itu agar diteruskan, bahkan ditingkan kualitasnya.

\section{SUMBER BACAAN}

Bagir. Haidar 2003. "Gagalnya Pendidikan Agama”, Harian Kompas, Jum'at 28 Februari 2003.

Direktur Jenderal Kelembagaan Agama Islam (2002):Buku KebijakanDirektur Jenderal Kelembagaan Agama Islam di Bidang Pendidikan Agama dan Keagamaan Islam. Jakarta, Direktur Jenderal Kelembagaan Agama Islam.

Djumiko. (2010) "Hubungan Timbal Balik antara Penghuni dengan Lingkungannya". Jurnal Teknik Sipil Dan Arsitektur, Fakultas Teknik Universitas Pembangunan Surakarta. Vol 8. Desember. (12 A).

Harian Kompas. 2003. "Pendidikan Agama di Sekolah Dinilai Gagal", 31 Mei 2003

Qowaid, dkk. (2003): Profil Guru Pendidikan Agama di Sekolah Umum. Jakarta, Puslitbang Pendidikan Agama dan Keagamaan.

(2007). Inovasi Pembelajaran Pendidikan Agama Islam. Jakarta, Pena Citasatria.

--------. ( 2008):Kajian Peraturan Dan Perundang-Undangan Pendidikan Agama Pada Sekolah. Jakarta, PT Pena Citasatria.

(2010): "Keinovatifan Dalam Penyuluhan Agama Islam Di Provinsi DKI Jakarta. Dialog, Jurnal Penelitian dan Kajian Keagamaan. Tahun XXXIII No 70. (119-138).

Peraturan Pemerintah Nomor 55 Tahun 2007 tentang Pendidikan Agama dan Keagamaan.

Peraturan Pemerintah Nomor 19 Tahun 2005 tentang Standar Nasional Pendidikan.

Putra. Kaharuddin Eka, dkk. Definisi tanggapan http: //kumpulanmakalahdanartikelpendidikan. blogspot.com/2011/02/tanggapan-menurut-psikologi-umum.html, diakes 26 maret 2013. 
Tholkhah. Imam (2010): Rencana Strategis Direktorat Pendidikan Agama Islam Pada Sekolah Tahun 2010 - 2014. Jakarta, Direktorat Jenderal Pendidikan Islam Kementerian Agama RI.

Tim Peneliti. (2011):Studi Perilaku Keberagamaan Peserta didik SMA, SMK dan Madrasah Aliyah (MA) di Pulau Jawa dan Sulawesi. Jakarta, Puslitbang Pendidikan Agama dan Keagamaan.
Wina, Sanjaya. (2012): Strategi Pembelajaran Berorientasi Standar Proses Pendidikan. Jakarta, Kencana.

Undang-Undang Republik Indonesia Nomor 20 Tahun 2003 tntang Sistem Pendidikan Nasional, Pasal 1 ayat 4.

Undang-undang Republik Indonesia Nomor 20 Tahun 2003 tentang Sistem Pendidikan Nasional. 